\title{
Teaching Reform of the Computer Engineering Talent's Innovation Ability Under the Background of Internet Plus
}

\author{
Hengyao Tang ${ }^{1,}$, , Xiaoyan Zhan ${ }^{2, b}$ \\ ${ }^{1}$ School of computer science, Huanggang Normal University, Huanggang 438000, China; \\ ${ }^{2}$ School of Foreign Studies, Huanggang Normal University, Huanggang 438000, China. \\ alinstar2007@163.com, b516556446@qq.com
}

\begin{abstract}
According to problem of lacking innovation ability and weak adaptability proposed by China engineering education quality report, the paper designed teaching model of six learning procedures based on Internet, including learning planning, online self-study, communication of doubtful points, lectures, application practice and competition promotion from the point view of cultivating innovation ability elements, which includes learning ability, observation ability, thinking ability, practical ability, expression ability and cooperation ability to make full use of the advantages of the Internet and the value of education resources and to achieve improvement of the comprehensive ability and stimulate students' innovation potential.
\end{abstract}

Keywords: Internet plus, Engineering talents, Innovation ability, Teaching reform.

\section{Introduction}

In April 2016, China's first release of "China's Higher Education Quality Report" [1] showed the overall quality of China's higher education in an all-round way, which positively affirmed the achievements made by China's higher education, and it pointed out the problems in China's higher education, among which the cultivation of innovative talents is not enough, and innovation and entrepreneurship education in colleges and universities is still the "weakness" which is one of the major problems. Engineering, scientific and technical personnel is the first strategic resource for building an industrial power. Can China's Engineering Education support Chinese manufacturing to Stand Out in Global Competition? Can it take the national strategic task in the new era? This is an inevitable proposition of the times. China Engineering Education Quality Report [2] which is guided by demand, showed the status quo, problems and solutions of China's engineering education quality from three perspectives: industry-oriented, world-oriented and the future-oriented. It pointed out that using advanced international concepts and standards to lead the reform of engineering education and improve the quality of engineering education; using the innovative education in the whole process of engineering students training, together with engineering education "blood"; and "return" project,[2] to regard the cultivation of students' ability as the quality of engineering education; to use the "Internet" to transform the engineering education and help to realize the dream of industrial power. [2] Computer engineering talents have unique gifts in using the Internet. To thoroughly study and use Internet to cultivate the innovative abilities of computer engineering talents meet the urgent demand of China's engineering education.

\section{The Internet + Education}

\subsection{The Internet's Educational Advantages}

There are lots of educational resources online which are rich in content and diverse in forms, for example:

(1) relatively systematic and complete: static teaching website for quality courses, electronic books, teaching PPT, dynamic course teaching video, micro-class animation video and so on;

(2) relatively fragmental and professional: Wanfang, CNKI and other electronic essays, all kinds of network shared library, interactive professional discussion exchange area, QQ exchange group, WeChat discussion group and so on; 
(3) relatively discontinuous and popular: professional cutting-edge news reports, various professional research reports, WeChat public subscription articles, teacher education blogs and so on;

(4) Need to excavate and analyze: the professional conditions of recruitment information, the professional subject of job interview, the professional learning experience of graduate students, all kinds of learning resources on the professional research and training websites.

\subsection{The Educational Value of the Internet}

The rich and varied learning resources on the Internet, the well-developed Internet environment in China and the low cost of access to the Internet have provided new impetus to our education.

(1) to stimulate students' interest in learning

Interest is the best teacher for students' learning, is the driving force for innovation. Among the Internet's rich and varied educational resources, there is always a match with the taste of students to find the students their favorite form of education, thereby stimulating student interest in learning.

(2) to cultivate students' initiative

Internet can be said to be a new and very useful educational encyclopedia. By increasing students' chances of using the basic knowledge of Internet to enable students to find their own answers, students' autonomous learning and initiative in learning can be cultivated.

(3) to exercise students' ability to communicate

Many students will post their learning problems on the Internet. No matter whether they know each other, profession or level, anyone who can answer can follow the thread and communicate. It not only increases the chances for students to communicate with all kinds of people in society, but also exercises their ability of communication.

(4) enhance students' ability to apply

Some enterprises will publish project outsourcing tasks on the Internet. Some employees will post their own problems that can't be solved in the project to the online forum for help. Some researchers will post their own problems in project experiments and invite others to analyze them. Students have access to the content on the Internet and can try to solve some of them. This exercise can enhance students' practical problem-solving skills, application capabilities of knowledge.

(5) develop students' cooperation spirit

Through the Internet students can exchange questions with all kinds of people in reality, and use their own knowledge to help others to solve problems in practical learning and work, which is a kind of collaborative process. Students are repeatedly engaged in these activities on the Internet, which can develop students' cooperation ability and create students' sense and spirit of cooperation.

\section{Teaching Reform Exploration of the Internet + Computer Engineering Talent Innovation Ability}

The popularization of the Internet, the Internet's rich educational resources, the close connection between the Internet itself and the computer science and exceeding of the limitation of time and space have provided favorable conditions for carrying out the innovation cultivation of Internet + computer engineering talents.

\subsection{Exploration of Internet + Teaching Reform Model}

Combining the advantages and the value of Internet education, from the perspective of exploring the potential of various elements of students' innovative abilities, we have designed a new teaching mode. The learning process is in Fig1 below: 


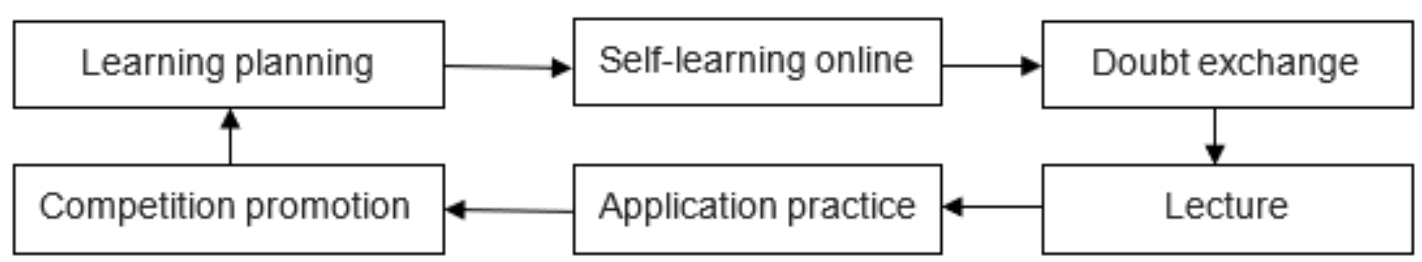

Fig 1. Module (stage) teaching mode diagram

\subsection{Learning Objectives and Content of Teaching Procedures}

Table 1. Learning Objectives and Contents in Teaching Links

\begin{tabular}{|c|c|c|}
\hline $\begin{array}{c}\text { Teaching } \\
\text { stage }\end{array}$ & learning target & Learning Content \\
\hline $\begin{array}{c}\text { Learning } \\
\text { planning }\end{array}$ & $\begin{array}{c}\text { Guide students to make } \\
\text { arrangements for learning; } \\
\text { stimulate students' interest in } \\
\text { learning }\end{array}$ & $\begin{array}{c}\text { The teacher introduced the knowledge and role } \\
\text { to be mastered according to the logic of the } \\
\text { course }\end{array}$ \\
\hline $\begin{array}{c}\text { Self-learning } \\
\text { online }\end{array}$ & $\begin{array}{c}\text { Give full play to the students' } \\
\text { personality and cultivate } \\
\text { students' autonomous learning } \\
\text { and active thinking }\end{array}$ & $\begin{array}{c}\text { Students discover knowledge of learning courses } \\
\text { from systematic education of the extensive } \\
\text { network resources based on personal } \\
\text { characteristics }\end{array}$ \\
\hline $\begin{array}{c}\text { Doubt } \\
\text { exchange }\end{array}$ & $\begin{array}{c}\text { Develop students' ability to } \\
\text { communicate and analyze, } \\
\text { solve problems }\end{array}$ & $\begin{array}{c}\text { Regular online or offline communication, the } \\
\text { students communicate and learn with each other } \\
\text { about those they do not understand in the stage } \\
\text { of self-learning and teachers listen aside }\end{array}$ \\
\hline $\begin{array}{c}\text { Lonsolidate the students' self- } \\
\text { learning knowledge, and } \\
\text { guide students to conduct } \\
\text { systematic summary, } \\
\text { demonstration, sublimation }\end{array}$ & $\begin{array}{c}\text { Teachers collect students' problems, and } \\
\text { combine them with the course knowledge, } \\
\text { carrying out classroom lectures in the form of } \\
\text { modules, and students extend and improve their } \\
\text { knowledge according to the lectures summary } \\
\text { and verification of stage self-learning. }\end{array}$ \\
\hline $\begin{array}{c}\text { Application } \\
\text { practice }\end{array}$ & $\begin{array}{c}\text { Enhance students' ability of } \\
\text { practicing and connecting } \\
\text { theory with practice }\end{array}$ & $\begin{array}{c}\text { Students focus on business and personal } \\
\text { application need online to carry out application } \\
\text { practice, and complete the practical task by the } \\
\text { offline teacher. }\end{array}$ \\
\hline $\begin{array}{c}\text { Cultivate team spirit and } \\
\text { comprehensive application } \\
\text { ability to stimulate innovation } \\
\text { potential }\end{array}$ & $\begin{array}{c}\text { Students form groups and teams to organize } \\
\text { comprehensive practice competitions quarterly } \\
\text { and participate in related competitions outside } \\
\text { the school }\end{array}$ \\
\hline
\end{tabular}

\subsection{Quality Assurance}

\subsubsection{Build a Wireless Campus}

To develop students' habit of surfing online to consult and verify the answers whenever they have questions in mind by allowing students to access the Internet anytime and anywhere, to look for and read materials, to exchange interactively, and learn systematically, which is helpful to cultivate students' autonomous study.

\subsubsection{Improve the Quality of Teachers}

Only by improving the overall quality of teachers in an all-round way can teachers play a leading role better and assure the application of the whole teaching procedures.

\subsubsection{Change the Examination Form}

The new teaching mode emphasizes the cultivation of students' qualities and abilities and their service for innovation. The traditional mid-term and final exam papers can't meet the examination 
needs which restrict students' enthusiasm for autonomous study. A variety of assessment forms with new assessment standards aimed at testing the students' comprehensive ability can better inspire students' learning motivation.

\subsubsection{Open Practice Environment}

The practice content should be simplified to increase the free and open laboratory time, and to allow students autonomously use the laboratory environment to organize their own practice learning.

\section{Conclusion}

In order to cultivate the innovation ability of engineering talents, we should start with the elements of innovation ability. Only by improving students' learning ability, discovery ability, practical ability, communication ability and cooperation ability can the students' innovative ability be nurtured and born. The paper starts from giving full play to students' individual initiative, digs the value of Internet educational resources in students' autonomous learning and designs new teaching modes which cultivate students' different abilities in different procedures, and finally enable students to comprehensively use their abilities through competitions to stimulate students' innovative potential.

\section{Acknowledgments}

The work is supported by the Teaching Research of Higher Education of Hubei Province, China (No. 2016407), the 2018 Project of Education Humanities and Social Sciences of Hubei Provincial Department (No.18D056), the Teaching Research Project of Huanggang Normal University (No.2016ce04).

\section{References}

[1]. Ministry of Education released. China's Higher Quality Report [N]. China Education Daily, 2016.4.

[2]. Ministry of Education released. China Engineering Quality Report [N]. China Education Daily, 2016.4 .

[3]. Gao Baoli. On the cultivation of college students innovative spirit and innovative ability [J]. Jiangsu Higher Education, 2003, (4): 1-4.

[4]. Lin Xiuhua, Wang Jian, Yang Cunrong, Yang Yonglin, etc. Innovative ability training [J]. Tsinghua University Education Research, 2002 (5): 41-44.

[5]. Zhu Qing Shi. How to develop their own innovative ability [C]. The Sixth Forum Proceedings of Chinese Scientists, Educators and Entrepreneur, 2007.8.

[6]. Liu Shuren. On the several tendencies in the implementation of innovative education[J]. Teaching and Management, 2001, (6): 7-9. 